\title{
PENERAPAN MEDIA AUDIO VISUAL UNTUK MENINGKATKAN KETERAMPILAN BERBICARA BAHASA INGGRIS SISWA KELAS V DI SD
}

\author{
Radode Kristianto Simarmata. \\ Universitas HKBP Nommensen Pematangsiantar, Indonesia. \\ Email: Radodesimarmata0@gmail.com
}

\begin{abstract}
ABSTARCT
Learning media can be found anywhere. Media has become apart of our lifes in our daily life. Now a days peoples are easier get an information and an enlightenment because of the learning media.The aims of the study is to find out the speaking skill learning effect of students of grade $V$ Primary Civil School 095135 Sipolha Horison,Pamatangsidamanik District, Simalungun Regency in learning English language before using Audio Visual Media. And to find out the Speaking skill effect of students of grade V Primary Civil School 095135 Sipolha Horison, Pamatangsidamanik District, Simalungun Regency after using an Audio Visual Media. From the research result and from the discussion taken by the author, we ot some conclusion: After adopting Audio Visual media, we know that students of grade V Primary Civil School 095135 sipolha Horison,Pamatangsidamanik District, Simalungun Regency are easier to understand the materials or an information which is delivered by the teacher. It means that the aim of the learning can be succeded effectifelly for the subject English language on Muatan lokal subject on students of grade V Primary Civil School 095135 Sipolha Horison,Pamatangsidamanik, District, Simalungun Regency.After developing English Language using an Audio Visual,proves that using an audio visual are more effectively than before taking the develope one.
\end{abstract}

Keywords : Audio Visual Media, Learning Videos, Speaking Skills

\begin{abstract}
ABSTRAK
Media pembelajaran dapat kita temukan di mana mana; media sudah menjadi bagian dari kehidupan sehari-hari kita. Pada saat ini Orang-orang lebih mudah mendapatkan informasi dan pencerahan berkat hadirnya media pembelajaran. Tujuannya Untuk mengetahui pengaruh peningkatan keterampilan berbicara Siswa kelas V di SD N 095135 Sipolha Horison, Kecamatan Pamatang Sidamanik, Kabupaten Simalungun, dalam pembelajaran mata pelajaran muatan lokal Bahasa Inggris sebelum menggunakan Media Audio Visual. Dan Untuk mengetahui pengaruh keterampilan berbicara S iswa kelas V di SD N 095135 Sipolha Horison, Kecamatan Pamatang Sidamanik, Kabupaten Simalungun dalam pembelajaran bahasa Inggris sesudah menggunakan Media Audio Visual. Dari hasil penelitian dan pembahasan yang dilakukan penulis, maka dapat ditarik kesimpulan sebagai berikut : Setelah dilakukan penerapan media audio visual berupa video pembelajaran bahasa inggris, dapat diketahui bahwa Siswa kelas V di SD N 095135 Sipolha Horison, Kecamatan Pamatang Sidamanik, Kabupaten Simalungun lebih mudah untuk memahami materi atau informasi yang disampaikan oleh Guru, apabila dibandingkan dengan penggunaan media sebelumnya. Artinya tujuan pembelajaran dapat tercapai secara lebih efektif untuk materi Mata Pelajaran Muatan Lokal Bahasa inggris pada siswa kelas V di SD N 095135 Sipolha Horison, Kecamatan Pamatang Sidamanik, Kabupaten Simalungun. Setelah adanya pengembangan pembelajaran Bahasa Inggris siswa dengan media A udio Visual terbukti pembelajaran lebih efektif apabila dibandingkan sebelum adanya pengembangan.
\end{abstract}

Kata Kunci: Media Audio Visual, Video Pembelajaran, Keterampilan Berbicara

\section{PENDAHULUAN}

Menghadapi era globalisasi sekarang ini peran Mata Pelajaran Muatan Lokal bahasa inggris sebagai bahasa internasional menjadi sangat penting karena semua informasi yang berhubungan kemajuan teknologi di buat atau di tulis dengan 
menggunakan bahasa Inggris. Selain itu untuk berkomunikasi dengan orang diluar Negara Indonesia diperlukan alat untuk berkomunikasi atau bertukar informasi, alat itu salah satunya adalah bahasa Inggris. Maka peranan bahasa inggris sangat besar dalam meningkatkan kemajuan teknologi dan komunikasi antar Negara. Maka dari itu generasi muda Indonesia dituntut untuk memiliki keterampilan berbahasa inggris. mendengar, membaca, menulis dan mengucapkan. dan Sejalan dengan itu para pemerintah daerah yang ada di Indonesia mengambil kebijakan untuk memasukkan bahasa inggris sebagai salah satu pelajaran tambahan yang sudah bisa di ajarkan dari sekolah-sekolah dasar.Tapi meskipun demikian rancangan yang telah disusun rapi oleh para pejabat yang berwenang. Tetapi masih banyak permasalahan- permasalahan yang ditemui dalam pengajaran bahasa inggris ini.

Permasalahan-permasalahan yang timbul disebabkan oleh beberapa hal. Diantaranya adalah minat belajar siswa untuk mempelajari bahasa Inggris, kurangnya minat ini disebabkan oleh kurangnya perbendaharaan kata dari siswa tersebut. Yang kedua waktu yang digunakan dalam pebelajaran Bahasa Inggris ini tidak cukup, karena untuk belajar bahasa inggris ini ada empat materi pokok yang mesti diajarkan, yaitu mendengar, membaca, menulis dan mengucapkan. Jadi dibutuhkan waktu extra untuk bias menghasilkan siswa siswa yang mampu berkomunikasi dengan menggunakan bahasa inggris. Yang ketiga peran guru dalam mengajarkan. Dalam pengajaran bahasa inggris, guru, khususnya guru kelas pada Muatan local bahasa inggris dituntut untuk lebih aktif dan menggunakan teknik-teknik yang kreatif dalam pengajaran. Kalau tidak dengan metode atau teknik yang menarik dalam pengajaran bahasa inggris ini akan menimbulkan kebosanan pada siswa. Hal inilah yang membuat siswa untuk malas belajar bahasa inggris yang akhirnya membuat mereka benci belajar bahasa inggris.

Yang dapat mempengaruhi proses pembelajaran bahasa Inggris. Diantaranya (a) waktu yang digunakan; (b) peran guru (c)Materi dan metode pengajaran yang di pakai; (d) Motivasi; (e) Fungsi Kognitif; (f) Keurutan pemerolehan; (g)Kepercayaan diri; (Interferensi bahasa; (h) Usia.

Sebenarnya ada banyak metode dalam pengajaran bahasa inggris ini. Salah satunya adalah dengan menggunakan alat atau media pembelajaran yang disertai dengan visualisasi atau yang lebih dikenal dengan Audio visual.

Audio visual berasal dari kata audible dan visible, audible yang artinya dapat didengar, visible artinya dapat dilihat. Dalam Kamus Besar Ilmu Pengetahuan, audio adalah hal-hal yang berhubungan dengan suara atau bunyi.

Audio berkaitan dengan indera pendengaran,pesan yang akan disampaikan dituangkan kedalam lambang-lambang auditif, baik verbal (kedalam kata-kata/ bahasa lisan) maupun non verbal.Visual adalah hal-hal yang berkaitan dengan penglihatan; berfungsi sebagai penglihatan diterima melalui indera penglihatan; dihasilkan atau terjadi sebagai gambaran dalam ingatan. Jadi Audiovisual adalah alat peraga yang bisa ditangkap dengan indra mata dan indra pendengaran yakni yang mempunyai unsur suara dan unsur gambar

Melihat perincian pengertian komponen-komponen yang ada, maka dapat disimpulkan bahwa media pembelajaran audio visual adalah sarana atau prasarana yang penyerapannya melalui pandangan dan pendengaran yang dipergunakan untuk membantu tercapainya tujuan belajar.

Pembelajaran menggunakan audio visual para siswa akan lebih mudah untuk mencerna permasalahan yang disampaikan. Karena pendengar dirangsang untuk menggunakan imajinasi dan mengoptimalkan fungsi otak mereka baik itu otak kiri 
ataupun otak kanan.

Untuk mengingat bahasa yang mereka pelajari lebih lama. Menurut Djamarah dan Zain (2010), media audio visual adalah media yang mempunyai unsur suara dan unsur gambar.

Arsyad (2011) berpendapat bahwa belajar dengan menggunakan indra ganda (audio visual), yaitu indra pendengaran dan penglihatan akan memberikan keuntungan bagi siswa karena siswa akan lebih banyak belajar daripada jika materi pelajaran disajikan dengan stimulus pandang saja atau dengar saja.

Peningkatan yang terjadi pada kelompok eksperimen dinilai berdasarkan peningkatan tahap-tahap pembelajaran dapat digolongkan menjadi enam tingkatan, berdasarkan dari tingkat paling sederhana sampai dengan tingkat paling sulit (Bloom, 1956). Tahap-tahap pembelajaran tersebut terbagi menjadi enam bagian.

Bagian-bagian tersebut adalah mengingat (remembering), memahami (understanding), menerapkan (applying), menganalisis (analysing), mengevaluasi (evaluating), dan menciptakan (creating). Penelitian ini bertujuan untuk meningkatkan kemampuan speaking siswa pada Mata Pelajaran Muatan Lokal Bahasa Inggris Siswa kelas V di SD N 095135 Sipolha Horison,Kecamatan PamatangSidamanik,Kabupaten Simalungun.

\section{Media}

Pengertian media menurut Asyhar. R (2010:22) menyatakan bahwa media adalah suatu sarana yang digunakan untuk menyampaikan pesan dari seorang komunikator kepada komunikan. Kemudian ditambahkan lagi oleh Sadiman (2008: 7) media pembelajaran adalah segala sesuatu yang dapat digunakan untuk menyalurkan pesan dari pengirim ke penerima pesan. Dalam hal ini adalah proses merangsang pikiran, perasaan, perhatian, dan minat serta perhatian siswa sehingga proses belajar dapat terjalin.

Berdasarkan kutipan diatas dapat disimpulkan bahwa media pembelajaran adalah sarana atau alat bantu yang digunakan untuk menyampaikan pesan atau materi pelajaran oleh guru terhadap siswa untuk meransang pikiran, perasaan, perhatian dan minat siswa sehingga proses belajar mengajar dapat terjalin dengan baik.

Menurut Chun, D. M (2012:16). Media is expected to play a critical role in enhancing academic performance. (Media diharapkan dapat memainkan peran penting dalam meningkatkan prestasi akademik). Sejalan dengan Barizzi. memiliki cakupan yang sangat luas, yaitu termasuk manusia, materi atau kajian yang membangun suatu kondisi yang membuat peserta didik mampu memperoleh pengetahuan, keterampilan atau sikap. Media pembelajaran mencakup semua sumber yang diperlukan untuk melakukan komunikasi dalam pembelajaran, sehingga bentuknya bisa berupa perangkat keras (hardware), seperti computer, TV, projector, dan perangkat lunak (software) yang digunakan pada perangkat keras itu.

Dari kutipan diatas dapat disimpulkan bahwa media pembelajaran merupakan suatu alat untuk membantu keberlansungan dan kemudahan proses belajar mengajar. Alat bantu tersebut berfungsi untuk memperjelas makna yang disampaikan sehingga tujuan pembelajaran akan dicapai dengan lebih baik. Ada beberapa jenis dan model media pembelajaran. Secara garis besarnya media pembelajaran ini dapat dikategorikan menjadi empat macam, yaitu media visual, media dengar, media proyeksi (proyected still), dan proyected motion media. 


\section{Jenis Media Pembelajaran}

Jenis-jenis media menurut Asyhar. R (2010: 17-18) mengklasifikasikan

media ke dalam tujuh kelompok yaitu.

1. Media audio, seperti: siaran berita bahasa Jawa dalam radio, sandiwara bahasa Jawa dalam radio, tape recorder beserta pita audio berbahasa Jawa.

2. Media cetak, seperti: buku, modul, bahan ajar mandiri

3. Media visual diam, seperti: foto, slide, gambar

4. Media visual gerak, seperti: film bisu, movie maker tanpa suara, video tanpa suara

5. Media audio semi gerak, seperti: tulisan jauh bersuara

6. Media audio visual diam, seperti: film rangkai suara, slide rangkai suara

7. Media audio visual gerak, seperti: film dokumenter tentang kesenian batak atau seni pertunjukan tradisional, video tor-tor Sombah, video wayang, video campursari.

Kemudian dijelaskan lagi oleh Suranto, (2013:5) mengelompokkan media pembelajaran menjadi beberapa jenis, yaitu: a. Media visual yaitu media yang hanya dapat dilihat, seperti foto, gambar dan poster. b. Media audio yaitu media yang hanya dapat didengar saja seperti kaset audio, MP3, dan radio. c. Media audio visual yaitu media yang dapat dilihat sekaligus didengar seperti film suara, video, televise dan sound slide. d. Multimedia adalah media yang dapat menyajikan unsur media secara lengkap seperti suara, animasi, video, grafis dan film. e. Media realia yaitu semua media nyata yang ada di lingkungan alam, seperti tumbuhan, batuan, air, sawah, dan sebagainya. Pengelompokan jenis-jenis media pembelajaran juga diungkapkan oleh Ashar (2011: 44) yaitu: a. Media visual yaitu jenis media yang digunakan hanya mengandalkan indra pengliatan misalnya media cetak seperti buku, jurnal, peta, gambar, dan lain sebagainya. b. Media audio adalah jenis media yang digunakan hanya mengandalkan pendengaran saja, contohnya tape recorder, dan radio. c. Media audio visual adalah film, video, program TV, dan lain sebagainya. d. Multimedia yaitu media yang melibatkan beberapa jenis media dan peralatan secara terintegrasi dalam suatu proses atau kegiatan pembelajaran.

Berdasarkan penjelasan di atas dapat disimpulkan bahwa media pembelajaran memiliki beberapa jenis, yaitu

(1) Media visual, Media visual yaitu media yang hanya dapat dilihat, seperti foto, gambar dan poster.

(2) Media audio, Media audio yaitu media yang hanya dapat didengar saja seperti kaset audio, MP3, dan radio.

(3) Media audio visual, Media audio visual yaitu media yang dapat dilihat sekaligus didengar seperti film suara, video, televise dan sound slide.

(4) Multimedia, dan Multimedia adalah media yang dapat menyajikan unsur media secara lengkap seperti suara, animasi, video, grafis dan film.

(5) Media realia. Media realia yaitu semua media nyata yang ada di lingkungan alam, seperti tumbuhan, batuan, air, sawah, dan sebagainya

Setiap jenis media pembelajaran memiliki bentuk dan cara penyajian yang berbeda-beda dalam pembelajaran audio visual.

\section{Media audio Visual}

Pengertian Media Audio Visual Menurut Madhuri, J. N. (2013: 12) pengertian Media Audio Visual berasal dari kata media yang berarti bentuk perantara yang digunakan oleh manusia untuk menyampaikan atau menyebar ide, gagasan, atau 
pendapat sehingga ide, pendapat atau gagasan yang dikemukakan itu sampai kepada penerima yang dituju. Azhar (2008 : 52) mengatakan media Audio Visual adalah media pengajaran dan media pendidikan yang mengaktifkan mata dan telinga peserta didik dalam waktu proses belajar mengajar berlangsung. Lebih jelas sanajaya (2011 : 211) menjelaskan bahwa Media Audio Visual yaitu jenis media yang selain mengandung unsur suara juga mengandung unsur gambar yang dapat dilihat, seperti rekaman video, berbagai ukuran film, slide suara, dan lain sebagainya. Kemampuan media ini dianggap lebih baik dan lebih menarik, sebab mengandung kedua unsur jenis media yang pertama dan kedua.

Dari kutipan diatas dapat disimpulkan bahwan Media Audio Visual adalah sejenis media yang mengandung unsur suara, gambar yang dapat dilihat, seperti rekaman video, berbagai ukuran film, slide suara, dan lain sebagainya.

\section{Prinsip-Prinsip Pemilihan Media}

Menurut Asyhar. R. (2010; 32) Menghasilkan suatu produk media pembelajaran yang baik maka diperlukan prinsip dalam pemilihan media. Dalam prinsip pemilihan media pembelajaran ada beberapa hal yang harus diperhatikan diantaranya sebagai berikut:

1. Mengidentifikasi media

2. Mengidentifikasi kerakteristik siswa

3. Mengidentifikasi karakteristik lingkungan belajar

4. Mempertimbangan media mana yang mudah dilaksanakan

5. Mengidentifikasi faktor ekonomi dan organisasi.

Pendapat yang sama dikemukakan oleh Saud (2009: 97) penggunakan media harus memperhatikan prinsip pemilihan media terlebih dahulu. Prinsip-prinsip dalam pemilihan media pembelajaran menurut saud adalah sebagai berikut: a. tepat guna, b. berdaya guna, c. bervariasi.

Dari kutipan di atas dapat disimpulkan bahwa prinsip pemilihan media pembelajaran ada beberapa hal yang harus diperhatikan diantaranya sebagai berikut:

1. Mengidentifikasi media yaitu pemilihan media yang cocok dan sesuai dengan kondisi, performance atau tingkat setiap tujuan pembelajaran

2. Mengidentifikasi kerakteristik siswa yaitu mengidentikasi karakter atau sifat siswa yang di ajar dengan menggunakan media ini

3. Mengidentifikasi karakteristik lingkungan belajar berkenaan dengan media pembelajar yang akan digunakan

4. Mempertimbangan media mana yang mudah dilaksanakan

5. Mengidentifikasi faktor ekonomi dan organisasi yang menentukan kemudahan penggunaan media pembelajaran.

Prinsip-prinsip lain dalam pemilihan media pembelajaran adalah:

a. Tepat guna, artinya media pembelajaran yang digunakan sesuai dengan kompetensi dasar

b. Berdaya guna, artinya media pembelajaran yang digunakan mampu meningkatkan motivasi siswa

c. Bervariasi, artinya media pembelajaran yang digunakan mampu mendorong sikap aktif siswa dalam belajar.

\section{Ketrampilan Berbicara}

Berbicara menurut Madhuri, J. N. (2013:5) bahwa berbicara adalah suatu 
keterampilan berbahasa yang berkembang pada kehidupan anak, yang hanya didahului oleh keterampilan menyimak, dan pada masa tersebutlah kemampuan berbicara atau berujar dipelajari.

Berbicara sudah barang tentu berhubungan erat dengan perkembangan kosa kata yang diperoleh oleh sang anak; melalui kegiatan menyimak dan membaca. Selanjutnya Tarigan (2008: 16) mengungkapkan bahwa bahasa adalah kemampuan mengucapkan bunyi-bunyi artikulasi atau kata-kata untuk mengekspresikan, menyatakan atau menyampaikan pikiran, gagasan, dan perasaan.

Sebagai perluasan ini berbicara merupakan suatu sistem tanda-tanda yang dapat didengar (audible) dan yang kelihatan (visible) yang memanfaatkan otot dan jaringan otot tubuh manusia demi maksud dan tujuan gagasan-gagasan atau ide-ide yang dikombinasikan. Lebih jauh lagi menurut Tarigan (2008: 17), berbicara merupakan suatu bentuk perilaku manusia yang memanfaatka faktor-faktor fisik, psikologis, neurologis, semantik, dan linguistik sedemikian ekstensif, secara luas sehingga dapat dianggap sebagai alat manusia yang paling penting bagi kontrol manusia.

Keterampilan berbicara adalah proses interaktif untuk membangun makna produksi, penerimaan dan pengolahan informasi ini dilakukan ketika seseorang berbicara karena pada saat itu dia mengungkapkan gagasan perasaan dan pemikirannya melalui komunikasi.

Pengembangkan keterampilan siswa untuk mengekspresikan diri melalui berbicara, merupakan komponen yang sangat penting dari kemampuan bahasa. Para siswa menghadapi banyak masalah dalam mempelajari keterampilan ini sehingga guru harus membantu siswa menyelesaikan ini, seperti guru memberikan contohcontoh atau intruksi yang mudah dimengerti oleh siswa dan menghindari kata atau kalimat yang tidak berhubungan dengan topic kalimat. Agar target pembelajaran yang sudah direncanakan tercapai. Siswa harus belajar menggunakan bahasa Inggris untuk berinteraksi dengan orang lain. Dalam kesempatan ini, siswa harus menguasai tata bahasa, kosa kata, dan kefasihan. Singkatnya, guru bahasa Inggris harus kreatif dalam mengembangkan proses belajar mengajar mereka untuk menciptakan suasana yang nyaman, meningkatkan ketrampilan berbicara siswa, memberi perhatian pada komponen berbicara dan membuat pelajaran bahasa Inggris lebih menarik.

\section{Aspek Keterampilan Berbicara}

Proses berbicara menurut Tarigan (2008:24) mengatakan bahwa "aspek berbicara terdiri dari ujaran, tata bahasa, kosa kata, kelancaran, isi, dan pemahaman". Kemudian Tarigan (2008:29) mengatakan berbicara pada hakikatnya merupakan suatu proses berkomunikasi, sebab di dalamnya terjadi pesan dari suatu sumber ke tempat lain.

Dari pengertian yang sudah disebutkan dapat disimpulkan bahwa berbicara merupakan suatu proses untuk mengekspresikan, menyatakan, serta menyampaikan ide, pikiran, gagasan, atau isi hati kepada orang lain dengan menggunakan bahasa lisan yang dapat dipahami oleh orang lain. Selanjutnya di jelaskan lagi oleh Tarigan (2008: 42) menyatakan bahwa "aktivitas berbicara dapat dilihat dari kesesuaian ucapan, penempatan stres, kesesuaian pilihan kata, kesesuaian target berbicara". Sementara, Jadi dapat dipahami keterampilan berbicara proses memahami komunikasi untuk menyampaikan ide, pikiran, gagasan, atau isi hati kepada orang lain dengan menggunakan bahasa lisan yang dapat dipahami oleh orang lain dengan kesesuaian ucapan, penempatan stres, kesesuaian pilihan kata, kesesuaian 
target berbicara".

\section{Tujuan dan Teknik Berbicara}

Menurut Tarigan (2008:16), tujuan utama dari berbicara adalah berkomunikasi. Lebih lanjut, Tarigan (2008:8) menegaskan bahwa manusia sebagai makhuk sosial tindakan pertama dan paling penting adalah tindakan sosial, suatu tindakan tepat saling menukar pengalaman, saling mengemukakan dan saling menukar pengalaman, saling mengemukakan dan menerima pikiran, saling mengutarakan perasaan atau saling mengekspresikan, serta menyetujui suatu pendirian atau atau keyakinan Komunikasi mempersatukan para individu ke dalam kelompok-kelompok dengan jalan menggolongkan konsep-konsep umum. Selain itu, menciptakan serta mengawetkan ikatan- ikatan kepentingan umum, menciptakan suatu kesatuan lambang-lambang yang membedakannya dari kelompok-kelompok lain, dan menetapkan suatu tindakan.

Menurut Ochs dan Winker (dalam Tarigan, 2008:10), pada dasarnya berbicara mempunyai tiga maksud umum, yaitu sebagai berikut.

1) Memberitahukan dan melaporkan (to inform),

2) Menjamu dan menghibur (to entertain),

3) Membujuk, mengajak, mendesak, dan meyakinkan (to persuade)

Dari kutipan diatas dapat diambil kesimpulan berbicara adalah berkomunikasi. yang dilakukan oleh manusia karena manuisa adalah makhuk sosial yang butuh saling menukar pengalaman, pikiran, saling mengutarakan perasaan atau saling mengekspresikan, serta menyetujui suatu pendirian atau atau keyakinan Komunikasi mempersatukan para individu ke dalam kelompok-kelompok dengan jalan menggolongkan konsep-konsep umum.

Selain itu, menciptakan ikatan-ikatan kepentingan umum, menciptakan suatu kesatuan lambang- lambang yang membedakannya dari kelompok- kelompok lain, dan menetapkan suatu tindakan.

\section{Menilai Berbicara}

Untuk mengetahui peningkatan kemampuan berbicara siswa telah dilakukan Para siswa Akan diukur dengan pengukuran yang diadaptasi dari Arthur Hughes Berkolaborasi dengan FSI (foreign service instate). Ada lima komponen miliki Ratting berkisar 1-5 dengan bobot poin yang berbeda dari yang terendah ke paling tinggi.

Pengukuran berbicara terdiri dari beberapa komponen yang diuraikan Keterampilan siswa dalam pengucapan.

\section{Tabel 1 Penilaian Keahlian Berbicara Aspek Penilaian:}

5 Berbicara dan aksen (style) mirip penutur asli

4 Sedikit kesalahan dalam pengucapan

3 Memerlukan konsentrasi tinggi agar terhindar dari kesalahan pemahaman

2 Sering melakukan kesalahan saat Berbicara

1 Pengucapan sering tidak bisa di mengerti 


\section{METODOLOGI PENELITIAN \\ Desain Penelitian}

Untuk mendapatkan hasil penelitian yang optimal harus digunakan metode penelitian yang tepat maka Pendekatan yang digunakan dalam penelitian kali ini adalah pendekatan kualitatif dan kuantitatif. Pendekatan kualitatif digunakan untuk menjabarkan karakteristik data-data yang ada, sedangkan pendekatan kuantitatif digunakan untuk mengukur suatu nilai dari data yang ada.

Pendekatan kuantitatif adalah pendekatan dimana peneliti hanya menggunakan klaim postpositif untuk mengembangkan pengetahuan (yaitu, pemikiran sebab dan akibat, pengurangan variabel spesifik dan hipotesis dan pertanyaan, penggunaan pengukuran dan pengamatan, dan uji ories), menggunakan strategi dari Penyelidikan seperti eksperimen dan survei, dan mengumpulkan data instrumen yang telah ditentukan yang menghasilkan data statistik Suharto, G. (2008: 21).

\section{Populasi}

Merupakan keseluruhan subjek populasi merupakan keseluruhan subjek penelitian yang mempunyai kualitas dan karakteristik tertentu yang ditetapkan oleh peneliti untuk dipelajari dan selanjutnya ditarik kesimpulan sesudah dilakukan penelitian. Populasi penelitian adalah seluruh siswa -siswi kelas V di SD N 095135 Sipolha Horison, Kecamatan Pamatang Sidamanik, Kabupaten Simalungun

\section{Sampel}

Karakteristik yang dimiliki oleh populasi (2008:118). Untuk itu sampel yang diambil dari populasi harus betul- betul representative (mewakili). Jadi responden dipilih secara acak dari siswa kelas V di SD N 095135 Sipolha Horison, Kecamatan Pamatang Sidamanik, Kabupaten Simalungun untuk diwawancarai secara terstruktur untuk menemukan data yang dibutuhkan dalam penelitian ini terdapat hanya 15 siswa kelas V Di SD N 095135 Sipolha Horison. Sehingga total sampel berjumlah 15 siswa sebagai responden dalam penelitian ini.

\section{Teknik Pengumpulan Data}

Teknik dalam memgumpulkan data pada penelitian ini adalah observasi yaitu dengan mengamati langsung proses belajar dan mengajar sampel Siswa kelas V di SD N 095135 Sipolha Horison, Kecamatan Pamatang Sidamanik, Kabupaten Simalungun Observasi ini dilakukan secara bertahap.Tahap pertama di lakukan sebelum menggunakan audio visual sebagai alat bantu pengajaran bahasa Inggris. Tahap kedua dilakukan setelah penggunaan audio visual sebagai alat bantu pengajaran bahasa Inggris. Dan tahap ketiga yaitu mengadakan evaluasi terhadap sistim pembelajaran sebelum menggunakan audio visual dan setelah menggunakan audio visual.

Selanjutnya, dilakukan Performance test keterampilan berbicara dan menggunakan kuisioner/ angket yaitu dengan memberikan penilaian keterampilan berbicara yang diisi oleh observer (peneliti) dan, berupa tes, terdapat beberapa gambar yang harus dijelaskan secara lisan oleh siswa (describing people based on the pictures) dan. Tes ini diberikan sebelum dan sesudah pembelajaran (one group pretestposttest design). Untuk mempermudah penyusunan instrumen, maka digunakan matrik pengembangan instrumen atau kisi-kisi instrumen.

Terakhir dokumentasi. Menurut Sugiyono (2008:202) menyatakan dokumentasi 
dalam pengertian luas, bahwa dokumentasi bukan hanya yang berwujud tulisan saja, tetapi dapat berupa bendabenda peninggalan seperti prasasti dan simbol-simbol. Metode dokumentasi ini dapat merupakan metode utama apabila peneliti melakukan pendekatan analisis isi. Data-data yang diambil peneliti sebagai bukti dokumentasi adalah data-data yang mendukung penelitian seperti catatan mengenai laporan kegiatan sekolah, rencana pengajaran guru, daftar mata pelajaran Siswa kelas V di SD N 095135 Sipolha Horison, Kecamatan Pamatang Sidamanik , Kabupaten Simalungun. Selain itu sebagai bukti autentik, peneliti mengambil gambar kegiatan pembelajaran guru dan peserta didik dalam bentuk picture (JPG)

\section{Model Penelitian}

Model Penelitian ini adalah penelitian yang bersifat kualitatif dan kuantitatif yang digunakan untuk meneliti pada kondisi objek yang alamiah dimana peneliti adalah sebagai instrument kunci. Pada penelitian ini, dalam hal ini peneliti akan melakukan investigasi dengan cara mengumpulkan data secara langsung atau tatap muka terhadap sumber data dan memberikan kuesioner yang akan di jawab oleh responden, kemudian melakukan analisis dengan prosedur statistik atau bentuk hitungan lainnya

\section{Teknik Analisis Data}

Setelah pengumpulkan data yang dibutuhkan dalam penelitian, maka langkah selanjutnya adalah menganalisis data penelitian. Analisis data dilakukan setelah data dari seluruh responden Dalam menganalisis data, data dikelompokan berdasarkan variabel dan jenis responden, kemudian data yang sudah dikelompokkan di tabulasi berdasarkan variabel dari seluruh responden, menyajikan data tiap variabel yang diteliti, melakukan perhitungan untuk menjawab rumusan masalah dan melakukan perhitungan untuk menguji hipotesis yang telah diajukan. Sugiyono, (2008: 215).

Secara garis besar, analisis data meliputi: Persiapan

a. Mengecek Nama dan kelengkapan identitas pengisi

b. Mengecek kelengkapan data

c. Mengecek macam isian data

Tabulasi

a. Memberikan skor (scoring) terhadap item- item yang perlu diberi skor.

b. Memberikan kode terhadap item-item yang diberi skor. Untuk pretest dan post test setiap jawaban diberi skor dari rentang 1- 5 .

c. Menghitung skor dari setiap jawaban baik pada pretest maupun posttest serta menghitung gain.

Gain adalah selisih antara nilai posttest dan pretest, gain menunjukkan peningkatan hasil belajar siswa pada suatu kelas setelah pembelajaran berlangsung.

\section{Teknik Penyajian Hasil Penelitian}

Penyajian hasil penelitian dengan membentuk uraian singkat, bagan, hubungan antar kategori, flowchart dan sejenisnya. Langkah selanjutnya dalam analisis data kualitatif menurut miles and Huberman (2008:21) penarikan kesimpulan dan verifikasi. Kesimpulan awal yang dikemukakan masih bersifat sementara, dan akan berubah bila tidak ditemukan bukti-bukti yang kuat yang mendukung pada tahap pengumpulan data berikutnya. Tetapi apabila kesimpulan yang dikemukakan pada tahap awal, didukung oleh bukti-bukti yang valid dan konsisten saat peneliti kembali ke lapangan mengumpulkan data, maka kesimpulan yang dikemukakan merupakan 
kesimpulan yang kredibel. Demikian kesimpulan dalam penelitian kualitatif mungkin dapat menjawab rumusan masalah yang dirumuskan sejak awal, tetapi mungkin juga tidak, karena seperti telah dikemukakan bahwa masalah dan rumusan masalah dalam penelitian kualitatif masih bersifat sementara dan akan berkembang setelah peneliti berada di lapangan.

\section{PENUTUP}

Dari hasil penelitian dan pembahasan yang dilakukan penulis, maka dapat ditarik kesimpulan bahwa setelah dilakukan pengembangan dengan diketahui bahwa Siswa SD N 095135 Sipolha Horison, Kecamatan Pamatang Sidamanik, Kabupaten Simalungun lebih mudah untuk memahami materi atau informasi yang disampaikan oleh guru, apabila dibandingkan dengan penggunaan sebelumnya.

Artinya tujuan pembelajaran dapat tercapai secara lebih efektif untuk materi mata pelajaran muatan lokal bahasa inggris pada Siswa kelas V di SD N 095135 Sipolha Horison, Kecamatan Pamatang Sidamanik, Kabupaten Simalungun

Setelah adanya pengembangan pembelajaran Bahasa Inggris untuk Siswa kelas V di SD N 095135 Sipolha Horison, terbukti lebih efektif apabila dibandingkan sebelum adanya pengembangan.

\section{DAFTAR PUSTAKA}

Shin, J.K. (2006). Ten Helphul ideas for Teaching English to young Learners. In English Teaching Forum (Vol. 44, p. 2)

Ramendra, D. P., Ratmingningsih, N.M (2006) study pemanfaatan alat bantu pembelajaran (Audio Visual Aids) dalam proses belajar mengajarmata pelajaran bahasa Ingris di sekolah dasar di kota Singaraja : Upaya Mengaktualisasikan kurikulum berbasis kompetensi. Laporan Penelitian . Singaraja : Universitas Pendidikan ganesha.

Tarigan, Henry Guntur, (2009) Metodologi Pengajaran Bahasa 2 Bandung : Angkasa

Paul, D., \& Chan, M. (2010). Teaching English to children in Asia.pearson Longman Asia.

Abe, Y. (2011). The effect of computer-mediated communication on Japanese EFL learners' acquisition. The Modern Language Journal, 80(2), 183-198.

Yessaei, S. (2012). Using Original Video And Sound Effect to Teach English in English teaching forum (Vol 50,pp. 12-16)

Madhuri, J. N. (2013). Use of Audio Visual Aids in Teaching and Speaking. Research Journal of english Language and Literature (RJELAL). Retrieved on December $20^{\text {th }} 2013$ Mason, The open University.

Suranto, (2013). Komunikasi Perkantoran.Yogyakarta: Media Wacana.

Sanjaya, W. 2013. Penelitian Jenis, Metode dan Prosedur. Jakarta : Kencana Prenada Media Group.

Wahyudin, 2013. Statiska Terapan. Bandung . Universitas Pendidikan Indonesia.

Sundaraya, R . 2014 Statistika Penelitian Pendidikan. Bandung . Alfabeta.

Sugiyono. (2016) Metode Penelitian Kuantitatif, Kualitatif, dan R\&D Bandung : Alfabeta.

Sujarwemi V. Wiratna (2015). SPSS Untuk Penelitian Yogyakarta : Pustaka Baru Press.

Yuliana (2018) Pengaruh Media Audio Visual terhadap Keterampilan Menyimak Mata Pelajaran Bahasa Indonesia Kelas V di SDN 1 Harapan Jaya Bandar Lampung. Pendidikan Guru Madrasah . Fakultas UIN Raden Intan Lampung. 